\title{
Pulpo-dentin complex response after direct capping with self-etch adhesive systems
}

\author{
Alicja Nowicka', Miroslaw Parafiniuk², Mariusz Lipski ${ }^{3}$, \\ Damian Lichota1, Jadwiga Buczkowska-Radlinska1 \\ ${ }^{1}$ Department of Conservative Dentistry, Pomeranian Medical University, Szczecin, Poland \\ ${ }^{2}$ Department of Forensic Medicine, Pomeranian Medical University, Szczecin, Poland \\ ${ }^{3}$ Department of Preclinical Conservative Dentistry and Preclinical Endodontics, Pomeranian \\ Medical University, Szczecin, Poland
}

\begin{abstract}
The purpose of the present study was to evaluate morphologically the response of feline teeth pulp to direct pulp capping with two different self-etch adhesive systems. Twenty-four cavities in feline teeth were mechanically exposed and assigned to one of two experimental groups: AdheSE + Tetric Ceram (the ASE group), or Adper Prompt L-Pop + Filtek Supreme (the APLP group). There was also a control group Dycal $\mathrm{Ca}(\mathrm{OH})_{2}$ liner + Amalgam (the $\mathrm{CH}$ group eight teeth), and six teeth were used as an intact control group. The animals were sacrificed after 40 days. The teeth were removed and processed for standard histological evaluation, using a scoring system for inflammatory cell response, pulp tissue disorganisation, reparative tissue formation, and the presence of bacteria. Statistical analysis revealed no significant differences between the ASE and APLP selfetching resin systems during the observation period. The majority of the specimens presented inflammatory pulp response with tissue disorganisation and a lack of dentinal bridge formation. $\mathrm{CH}$ capping resulted in a significantly smaller inflammatory pulp response and a considerably higher incidence of reparative dentin formation. ASE and APLP were comparably effective as direct pulp capping materials, but their application resulted in significantly greater pulp tissue damage than $\mathrm{CH}$ capping. Further in vivo human studies are necessary to determine which adhesive resin systems should be clinically used for direct pulp capping without incurring severe damage to the pulpal tissue. (Folia Histochemica et Cytobiologica 2012, Vol. 50, No. 4, 565-573)
\end{abstract}

Key words: biocompatibility, direct pulp capping, dental adhesive resins, pulpal reaction, self-etching adhesive system, feline teeth, histology

\section{Introduction}

Evaluation criteria for healing exposed pulp typically include the differentiation of odontoblast-like cells, the formation of a hard tissue barrier across the exposed area, and the absence of inflammation in the adjacent tissue [1-8]. Protection of the pulpo-dentin complex, under restorative material, involves the application of materials to dental tissues to avoid addi-

\footnotetext{
Correspondence address: A. Nowicka,

Department of Conservative Dentistry,

Pomeranian Medical University, Szczecin, Poland;

tel.: + 489146616 48; fax:+ 489146617 44;

e-mail: nowicka6@gmail.com
}

tional challenges to the pulp tissue by mechanical trauma, operating procedures, toxicity of the material used, and bacterial penetration due to microleakage. Numerous studies have shown that $\mathrm{Ca}(\mathrm{OH})_{2}$ should be considered the gold standard for the treatment of pulp wounds [1-6], by stimulating the formation of dentin bridges and consequently leading to pulp healing, and thus providing high success rates for clinical procedures. However, $\mathrm{Ca}(\mathrm{OH})_{2}$ has been reported to dissolve over time, and dentin bridges adjacent to the material may contain multiple tunnel defects that open to the underlying pulp. As a result, this material may fail to provide an effective long-term barrier against bacterial penetration [9]. New pulp capping techniques may stimulate pulp healing through complete dentin bridge formation with no chemical toxic 
Table 1. Commercial names and compositions of products tested in the current study

\begin{tabular}{|c|c|c|c|}
\hline Products tested & Manufacturer & Classification & Composition \\
\hline AdheSE & $\begin{array}{l}\text { IvoclarVivadent } \\
\text { Schaan, } \\
\text { Liechtenstein }\end{array}$ & $\begin{array}{l}\text { Two-step self-etch } \\
\mathrm{pH}=1.69\end{array}$ & $\begin{array}{c}\text { Primer: dimethacrylate phosphonic acid acrylate, } \\
\text { initiators, and stabilisers in an aqueous solution. } \\
\text { Bond: HEMA, dimethacrylate, silicon dioxide, } \\
\text { initiators, and stabilisers }\end{array}$ \\
\hline $\begin{array}{l}\text { AdperPrompt } \\
\text { L-Pop }\end{array}$ & $\begin{array}{c}\text { 3M ESPE } \\
\text { Seefeld, Germany }\end{array}$ & $\begin{array}{l}\text { One-step self-etch } \\
\mathrm{pH}=0.35\end{array}$ & $\begin{array}{c}\text { Liquid A: HEMA, polyalkenoic acid, } \\
\text { stabilisers, water. Liquid B: methacrylated } \\
\text { phosphoric ester, Bis-GMA, initiators based } \\
\text { on comphorquinone, stabilisers }\end{array}$ \\
\hline Dycal & $\begin{array}{l}\text { Dentsply, Caulk, } \\
\text { Milford, DE, USA }\end{array}$ & $\begin{array}{l}\text { Control, hard-setting } \\
\mathrm{Ca}(\mathrm{OH})_{2} \text { cement } \\
\mathrm{pH}=11.1\end{array}$ & $\begin{array}{l}\text { Base paste: calcium tungstate, zinc oxide, disalicylate } \\
\text { ester of } 1,3 \text { butylene glycol. Catalyst paste: } \\
\text { calcium hydroxide, zinc oxide, titanium dioxide }\end{array}$ \\
\hline
\end{tabular}

Bis-GMA — bisphenol A glycidyl methacrylate; HEMA — 2 hydroxyethyl methacrylate

effects, thus providing better results than $\mathrm{Ca}(\mathrm{OH})_{2}$ [9-11].

In recent years, dentin bonding systems (DBSs) have been examined in humans [1, 4, 7, 12-19] and animals $[2,5,9-11,20-29]$ as potential direct capping materials due to their superior ability to adhere to demineralised dentin tissues. Hybridisation of DBSs and diffusion of adhesives into the dentin tubules may protect the dentin against bacterial leakage and reduce secondary pulpal inflammation. Scarano et al. [7] and Medina et al. [21] reported that direct pulp capping with DBS in most cases did not result in inflammation, and in some patients induced dentin bridge formation. However, Sano et al. [30] demonstrated leakage within the hybrid layer through nanometric spaces. Other extensive studies have revealed cytotoxicity of components of the adhesive systems and composite resins, such as bisphenol A-glycidyl methacrylate (Bis-GMA), urethane dimethacrylate, tri-ethylene glycol dimethacrylate, camphoroquinone, and 2-hydroxyethyl methacrylate (HEMA) [31-32]. When applied to dentin, these monomers were able to diffuse through the dentin tubules and reach the pulpal space. However, long periods of cellular exposure to these monomers resulted in a significantly increased cytotoxicity [32-34]. Studies of human [1, 4, 12, 15], dog [2, 22-23], monkey [24] and cat [25] teeth have reported adverse effects of the application of DBSs as pulp capping agents. Etch-andrinse bonding agents applied on pulp exposed following acid etching elicited a moderate inflammatory response in a short-term evaluation, which sometimes led to pulp necrosis $[1,4,12,16]$.

The wide range of chemical compounds of adhesive systems [16-17] may be responsible for the different biological responses when employed as pulp capping agents. Recent progress has led to the development of two-step and one-step self-etch adhesive systems in which etching, priming, and bonding are performed simultaneously. An example of a two-step adhesive system is the AdheSE system manufactured by Vivadent; an example of a one-step system is the Adper Prompt L-Pop system manufactured by $3 \mathrm{M} / \mathrm{ESPE}$. These adhesive systems present different application techniques and chemical compounds (Table 1), which may allow for pulp repair as well as dentin bridging. The self-etching bonding agent does not require prior total etching. Additionally, self-etching primers are less acidic than phosphoric acid $(\mathrm{pH}<0.2)[33]$. Phosphoric acid etching has been previously shown to considerably increase dentin permeability and monomer diffusion. In vitro and in vivo studies have demonstrated that self-etch adhesives can provide a more favourable response than etchand-rinse systems [15, 17, 33]. Demarco et al. [17] demonstrated that etch-and-rinse Scotchbond MultiPurpose presented mild to severe inflammatory response, and no mineralised tissue formation; however, the two-step self-etching adhesive system, Clearfil Liner Bond 2, exhibited dentin bridge formation in $50 \%$ of human specimens.

Several experimental studies $[2,5,7]$ have evaluated histopathologically the response of pulp capping with the Adper Prompt L-Pop system. Dentin bridge formation was not observed, and the remaining pulp tissue exhibited severe inflammatory alterations and areas of necrosis [2, 5]. However, Scorano et al. [7] found that pulp capping with the Prompt L-Pop system provided an acceptable degree of pulpal inflammatory responses. To date, there have been no published clinical studies on animals or humans regarding the use of direct pulp capping with the AdheSE system. The AdheSE system is provided with novel resin monomers, the phosphonic acid ether acrylates, which are claimed to have a high hydrolytic stability. Thomsen et al. [35] reported that the self-etching 
Table 2. Criteria and scores used for histological assessment

\begin{tabular}{|c|c|}
\hline Scores & Characterisation \\
\hline & Inflammatory cell response \\
\hline 0 & None or few scattered inflammatory cells present in the pulp area corresponding to the pulp exposure \\
\hline 1 & Low-grade inflammatory cell infiltrate with polymorphonuclear (acute) or mononuclear leukocytes (chronic) \\
\hline 2 & Moderate inflammatory cell infiltrate involving the coronal pulp \\
\hline \multirow[t]{2}{*}{3} & Severe inflammatory cell infiltrate involving the coronal pulp or present as abscess \\
\hline & Pulp tissue disorganisation \\
\hline 0 & Normal or almost normal tissue morphology \\
\hline 1 & Odontoblastic layer disorganised, with central pulp normal \\
\hline 2 & Total disorganisation of pulp tissue morphology \\
\hline \multirow[t]{2}{*}{3} & Pulp necrosis \\
\hline & Reparative tissue formation \\
\hline 0 & Absence \\
\hline 1 & Modest hard tissue deposition beneath the exposed area \\
\hline 2 & Moderate hard tissue deposition beneath the exposed area \\
\hline \multirow[t]{2}{*}{3} & Intense hard tissue deposition beneath the exposed area appearing as a complete dentin bridge \\
\hline & Presence of bacteria \\
\hline 0 & Absence \\
\hline 1 & Presence of stained bacteria along the cavity lateral walls \\
\hline 2 & Presence of stained bacteria along the cavity lateral and axial walls \\
\hline 3 & Presence of stained bacteria along the cavity walls and within the cut dentin tubules or over the pulp tissue \\
\hline
\end{tabular}

adhesives AdheSE $(27 \pm 6 \mathrm{MPa})$ revealed stronger adhesion than Adper Prompt-L-Pop $(19 \pm 6 \mathrm{MPa})$ on dentin, which improved the marginal integrity and better prevented microleakage. This system was also less acidic $(\mathrm{pH}=1.69)$ than APLP $(\mathrm{pH}=0.36)$ and could reduce deleterious effects on the pulp tissue [33]. Costa et al. [26] demonstrated that the two-step self-etching adhesive system, Clearfil Liner Bond 2, allowed pulp healing and tertiary dentin deposition. Other studies [17, 20, 27] have reported similar pulphealing responses with self-etching systems.

In vivo studies are required to understand the pulp response when adhesive systems are used as direct pulp capping. In general, animal studies are necessary since they provide results generating a wealth of valuable information from which it is possible to extrapolate results to humans. In the animal model, it is possible to treat all the teeth identically, controlling their history, care, and extraction under laboratory conditions to provide comparative evaluation of the biocompatibility of different dental materials [23, 26]. The present investigation performed on animals was aimed to provide direct information about the biocompatibility of dental materials and avoiding the exposure of humans to potentially harmful agents.
The purpose of the present study was to evaluate the response of the pulpo-dentin complex after direct capping with one-step or two-step self-etch adhesive systems (Adper Prompt L-Pop and AdheSE, respectively) in feline teeth. The null hypothesis considered in this study was the lack of differences in the pulpo-dentin complex response to three capping techniques (calcium hydroxide, one-step and two-step selfetch adhesive systems) applied as direct pulp capping in non-human teeth.

\section{Material and methods}

The present experimental work involved 38 teeth from three healthy 14 month-old felines. The study protocol, which adhered to ethical guidelines for animal care, was approved by the Local Ethical Committee, Pomeranian Medical University, Szczecin, Poland (approval number BN-060/17/05). The dental materials tested in this study and their chemical compositions are summarised in Table 1.

Operating procedure. Feline dentition examination was conducted under general anaesthesia (ketamine, atropine, and xylamine) normally used for common surgical operations on these animals. The oral cavity was disinfected with 
$0.2 \%$ chlorhexidine gluconate, and each tooth was pumiced with a rubber cup at low speed. The teeth were then divided into one of two experimental groups: AdheSE + Tetric Ceram (group ASE; IvoclarVivadent), Adper Prompt L-Pop + Filtek Supreme (group APLP; 3M ESPE), and a control group DycalCa $(\mathrm{OH})_{2}$ liner + Amalgam (group CH; Densply). Six intact teeth were selected as a negative control group, which received no exposure or pulp capping. The teeth were clinically intact and noncarious, with no more than superficial attrition and no signs of trauma. Thirty-two cavities were prepared using round and cylindrical diamond burrs (ISO size 010) at high-speed and copious water irrigation, extending to a depth of $\sim 1.0 \mathrm{~mm}$ to expose the pulp tissue. New burrs were used for each tooth. Cavities were isolated with sterile cotton rolls and saliva was controlled with high-speed evacuation.

Experimental and control groups. In the ASE group, teeth ( $\mathrm{n}=12$ ) were capped with AdheSE (IvoclarVivadent; Table 1), and resin composite Tetric Ceram (IvoclarVivadent) in accordance with the manufacturer's instructions. The cavity walls and exposed pulp were primed with AdheSE Primer for 30 seconds, air-dried, and coated with the bonding agent AdheSE Bond, which was light-cured for 20 seconds. APLP group teeth $(n=12)$ were capped with Adper Prompt L-Pop (3M ESPE; Table 1) and resin composite Filtek Supreme (3M ESPE) according to the manufacturer's instructions. The cavity walls and exposed pulp were conditioned with a mixture of Liquid I (red blister) and Liquid II (yellow blister) for 15 seconds. The bonding agent was air-dried until a thin, shiny, uniform layer was obtained, then lightcured for 20 seconds. $\mathrm{CH}$ teeth $(\mathrm{n}=8)$ were capped with $\mathrm{Ca}(\mathrm{OH})_{2}$ hard setting cement (Dycal, Dentsply) applied to the exposed pulp. The cavities were restored with the amalgam (Lumicon, Bayer Dental).

Cavities capped with the AdheSE and AdperPromt L-Pop systems were filled in two increments with Tetric Ceram or Filtek Supreme composites, respectively, and lightcured for 20 seconds after each increment. A light-curing unit (Astralis 3, Ivoclar, Vivadent) emitting more than $500 \mathrm{~mW} / \mathrm{cm}^{2}$ was used for polymerisation.

Assay of pulp bleeding. Bleeding was controlled by abundant irrigation with sterile saline solution and the placement of sterile cotton pellets into the pulp exposure sites. After controlling the bleeding, the cavities were primed for five seconds and dried for another five seconds. Consecutive coats of adhesive were applied to the exposed pulp and cavity walls and light-cured for 20 seconds. Pulp bleeding was classified into four categories adapted from Matsuo et al. [18]:

Absent None apparent from the pulp exposure site Slight Slight but apparent from the pulp exposure site - easily controlled by drying with sterile cotton pellets
Moderate Stopped in up to 30 seconds following 3-5 irrigation phases with saline and by drying with sterile cotton pellets

Abundant Persistent for more than 30 seconds $-5+$ irrigation phases necessary for complete haemorrhage control

Pulp tissue responses were assessed in a consecutive postoperative period of 40 days. At the end of the experimental period, the animals were sacrificed by intravenous injection of $200 \mathrm{mg} / \mathrm{kg}$ pentobarbital sodium.

Assay of periapical response. The maxilla and mandible with teeth were removed from each feline and radiographs were taken to detect periradicular tissue changes following the restorations. The status of periradicular tissue was evaluated for the absence or presence of apical pathology:

- normal periapical tissue - no change in the periradicular tissue;

- pathology in the periapical tissue — changes in the appearance of the apical periodontium such as widening of the periodontial ligament, changes in trabecular pattern, disintegration of lamina dura, osteolysis, or osteosclerosis.

Evaluation of histological features. The teeth were removed from the jaws and immersed in $10 \%$ neutral-buffered formalin (v/v) for two weeks. After applying a decalcifying solution of $6 \%(\mathrm{v} / \mathrm{v})$ nitric acid, the teeth were embedded in paraffin. Six micron-thick serial sections were stained with haematoxylin and eosin for routine histopathological evaluation. Bacteria were detected using the Brown and Brenn staining technique. The slides were observed under a light microscope (Carl Zeiss Imager D1 Axio) connected to a high-resolution video camera (Axio Cam MRc5 Carl Zeiss Microimaging) and interfaced to a monitor and a personal computer.

All stained sections were evaluated as described previously [1, 12, 21, 36] for inflammatory cell response, pulp tissue disorganisation, reparative tissue formation and the presence of bacteria. Each histological section was scored from 0 to 3, as shown in Table 2.

Statistical analysis. The mean scores assigned to the subitems for each of the five criteria (bleeding, inflammatory cell response, pulp tissue disorganisation, reparative hard tissue formation, and presence of bacteria) were analysed with the non-parametric Kruskal-Wallis test. Between-group comparisons were performed with the Mann-Whitney $\mathrm{U}$ test. $\mathrm{P}<0.05$ was considered significant.

\section{Results}

\section{Bleeding assessment}

The largest number of cases with bleeding (three) occurred in the ASE group, with only one case each 
Table 3. Assessment of bleeding levels immediately after capping

\begin{tabular}{|l|c|c|c|c|c|c|c|c|c|}
\hline \multicolumn{10}{|c|}{ Bleeding levels } \\
\hline \multirow{2}{*}{ Capping material } & \multicolumn{2}{|c|}{ Absent } & \multicolumn{2}{|c|}{ Slight } & \multicolumn{2}{|c|}{ Moderate } & \multicolumn{2}{|c|}{ Abundant } & \multirow{2}{*}{ Mean score } \\
\cline { 2 - 11 } & $\mathbf{n}$ & $\%$ & $\mathbf{n}$ & $\%$ & $\mathbf{n}$ & $\%$ & $\mathbf{n}$ & $\%$ & \\
\hline ASE & 9 & 75 & 2 & 16.7 & 1 & 8.3 & 0 & 0 & 0.33 \\
\hline APLP & 11 & 91 & 1 & 8.3 & 0 & 0 & 0 & 0 & 0.08 \\
\hline CH & 7 & 87.5 & 1 & 12.5 & 0 & 0 & 0 & 0 & 0.13 \\
\hline
\end{tabular}

The differences between three experimental groups were not statistically different according to the Mann-Whitney U test and the Kruskal-Wallis test

in the APLP and CH groups (Table 3). The bleeding observed in the APLP group was the least intensive during a direct pulp capping procedure. No significant differences were detected between the experimental and control groups, and when bleeding occurred after capping, it was generally slight or moderate. Abundant bleeding was not observed in any case.

In most cases, the self-etching adhesive system did not cause the bleeding process.

\section{Radiological assessment}

Periapical pathologies were not revealed by radiography.

\section{Histological assessment}

ASE group

A majority of the specimens capped with the ASE system presented low-grade inflammatory pulp responses with tissue disorganisation (Figure 1, Table 4). Moderately intense inflammation was observed in one case, while total tissue disorganisation was found in two. The odontoblast layer adjacent to the exposed pulp was disrupted or occasionally absent, with vascular dilatation and congestion, and features of chronic inflammation. Two specimens exhibited modest hard tissue deposition, but none of the teeth from this group displayed complete hard barrier formation. No specimens stained positively for bacteria.

\section{APLP group}

In the APLP experimental group, the pulp responses were similar to the ones observed in the ASE group (Figure 2, Table 4). In most teeth, pulp displayed lowgrade to moderate chronic inflammatory responses. Moderate inflammation and total tissue disorganisation were observed in two and one of the specimens, respectively. Incomplete amorphous dentin bridge

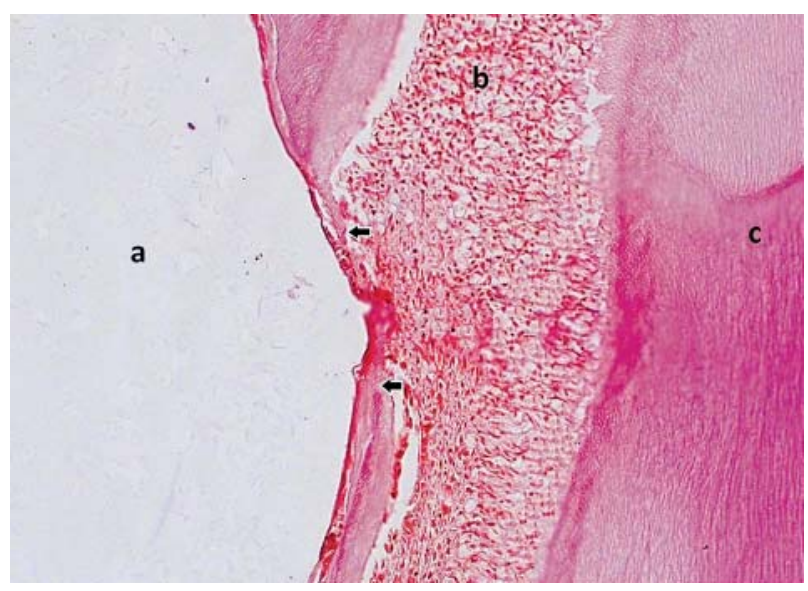

Figure 1. Pulp morphology of a feline tooth capped with ASE. Incomplete amorphous dentin bridge formation (black arrow). Cavity restoration (A); pulp (B); dentin (C). $\mathrm{H} \& \mathrm{E}$ staining, total magnification $400 \times$

formation with varying degrees of mineralisation occurred in two specimens; none of the teeth from this group displayed complete hard barrier formation. No specimens stained positive for bacteria.

\section{$\mathrm{CH}$ group}

The histological aspects of pulp tissue following $\mathrm{CH}$ treatment are shown in Figure 3. No moderately-intense inflammation or total tissue disorganisation were found in any of the $\mathrm{CH}$ specimens (Table 4). The adjacent pulp tissue exhibited no or few scattered inflammatory cells associated with a few dilated blood vessels, and six of the eight $\mathrm{CH}$ teeth exhibited slight disorganisation of the pulp tissue in the superficial zone. In two specimens, thin complete dentin bridge formation ( $12.1 \mu \mathrm{m}$ and $9.5 \mu \mathrm{m})$ with varying degrees of mineralisation and odontoblast-like cells were observed (Figure 3, Table 4). No specimens stained positive for bacteria. 


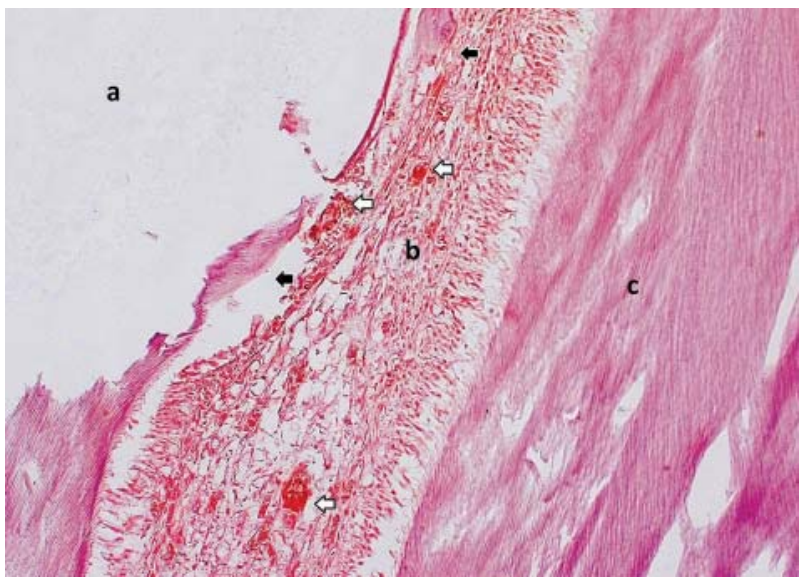

Figure 2. Pulp morphology of a feline tooth capped with APLP. Note congestion in the stroma of the pulp tissue (white arrow) and incomplete amorphous dentin bridge formation (black arrow). Cavity restoration (A); pulp tissue (B); dentin (C). H\&E, $200 \times$

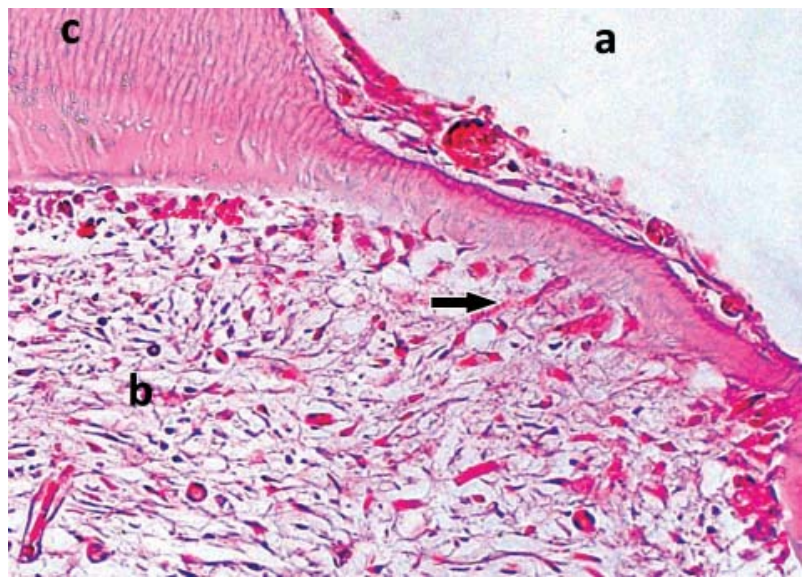

Figure 3. Pulp tissue of a feline tooth capped with $\mathrm{CH}$. Complete hard tissue bridge formation (black arrow) and normal soft tissue organisation beneath the exposed site. Cavity restoration (A); pulp tissue (B); dentin (C). H\&E, $200 \times$

Table 4. Characteristics of the pulp reaction to the applied capping systems

\begin{tabular}{|c|c|c|c|c|c|c|c|}
\hline \multirow{2}{*}{$\begin{array}{l}\text { Experimental } \\
\text { result }\end{array}$} & \multirow[t]{2}{*}{ Score } & \multicolumn{4}{|c|}{ Number of teeth } & \multirow[t]{2}{*}{ Mean score } & \multirow[t]{2}{*}{ p-value } \\
\hline & & $\mathbf{0}$ & 1 & 2 & 3 & & \\
\hline \multirow[t]{4}{*}{ Inflammatory cell response } & ASE & 3 & 8 & 1 & 0 & 0.83 & \\
\hline & APLP & 3 & 7 & 2 & 0 & 0.92 & 0.044 \\
\hline & $\mathrm{CH}$ & 6 & 2 & 0 & 0 & 0.25 & \\
\hline & \multicolumn{7}{|c|}{${ }^{\#} \mathrm{ASE} v . \mathrm{CH} \mathrm{p}<0.05 ;{ }^{\#} \mathrm{APLP} v . \mathrm{CH} \mathrm{p}<0.05$} \\
\hline \multirow[t]{3}{*}{ Tissue disorganisation } & ASE & 1 & 9 & 2 & 0 & 1.08 & \multirow{3}{*}{$0.179 \mathrm{~ns}$} \\
\hline & APLP & 0 & 11 & 1 & 0 & 1.08 & \\
\hline & $\mathrm{CH}$ & 2 & 6 & 0 & 0 & 0.75 & \\
\hline \multirow[t]{4}{*}{ Hard tissue formation } & ASE & 9 & 2 & 1 & 0 & 0.33 & \multirow{3}{*}{0.001} \\
\hline & APLP & 10 & 2 & 0 & 0 & 0.17 & \\
\hline & $\mathrm{CH}$ & 1 & 3 & 2 & 2 & 1.63 & \\
\hline & \multicolumn{7}{|c|}{${ }^{\#}$ ASEvs $\mathrm{CH} \mathrm{p}<0.01 ;{ }^{\#}$ APLPvsCH, $\mathrm{p}<0.01$} \\
\hline \multirow[t]{3}{*}{ Bacterial presence } & ASE & 12 & 0 & 0 & 0 & 0 & \multirow{3}{*}{ ns } \\
\hline & APL & 12 & 0 & 0 & 0 & 0 & \\
\hline & $\mathrm{CH}$ & 8 & 0 & 0 & 0 & 0 & \\
\hline
\end{tabular}

"Kruskal-Wallis test; ns — not significant ( $>$ > 0.05); \#Mann-Whitney U test

Negative control group

A control group consisting of intact teeth permitted evaluation of the histological processing of specimens. The pulp tissue in the intact control group exhibited an odontoblast layer, a zone of Weil, a cellrich zone, and central pulp with normal characteristics. No specimens stained positive for bacteria (Table 4).

\section{Statistical evaluation}

Bleeding assessments in the three experimental groups were not statistically different according to the Mann-Whitney U test and the Kruskal-Wallis test (Table 3).

Histological assessment data revealed no significant differences among the APLP and ASE groups 
( $p>0.05$; Kruskal-Wallis test). $\mathrm{Ca}(\mathrm{OH})_{2}$ capping resulted in a significantly lower number of inflammatory cells in the pulp tissue $(\mathrm{p}<0.05)$, and a notably higher incidence of reparative dentin formation $(p<0.01)$ than in either the ASE or APLP procedure (Table 4).

\section{Discussion}

In this study, one out of 12 teeth capped with ASE, and two out of 12 teeth capped with APLP, showed moderate inflammatory pulp responses. None of the teeth from these groups displayed complete hard barrier formation. In contrast, the teeth in the control group, capped with Dycal, showed favourable histopathological results. Therefore, the null hypothesis considered in this study that there are no differences in the pulpo-dentin complex response to three capping techniques (calcium hydroxide, one-step and two-step self-etch adhesive systems) application as a direct pulp capping in non-human teeth, cannot be accepted.

Adverse pulpal responses may result from factors such as operating procedures, bacterial penetration due to microleakage, and toxicity of the material [1-2, 5, 9-10, 15, 18, 27-29, 37-38]. Specific operating procedures used during capping may be critical for pulp tissue healing; controlling bleeding and blood clot formation is also critical for a successful direct capping $[5,18,27]$. In the present study, pulp bleeding was controlled only by irrigation with saline solution and the placement of sterile cotton pellets onto the pulp exposure sites. Effective haemostasis with saline solutions has been reported previously $[3,4$, 15]. Neither self-etch adhesive system used in the present investigation (AdheSE and AdperPromt L-Pop) require a separate acid etching step, which prevents the recurrence of bleeding after etching. The bleeding generated by APLP was the smallest during direct pulp capping procedures (Table 3 ). In some cases, contact of the pulp tissue with ASE started the bleeding process, thus damaging the adhesive properties. Similar results after direct pulp capping have been described in animal teeth by Kiba et al. [10] and in human teeth by Silva et al. [4].The effect of selfetching bonding systems on the control of pulpal bleeding in direct pulp exposures was evaluated in a study of contraction of pulp blood vessels in the rat carotid artery model [39]. Dose-dependent smooth muscle relaxations caused by the bonding agents were compared with papaverine's effects. Four dentinebonding agents produced dose-dependent relaxation, while APLP produced epinephrine-like contractions of the rat carotid artery [39]; observations from our study are similar.

In the present in vivo study, none of the specimens in the hard-setting $\mathrm{Ca}(\mathrm{OH})_{2}$ cement control group presented moderate inflammatory pulpal reaction, in contrast to the two investigated self-etch systems (Table 4), which showed in the pulp tissue located below the chronic inflammatory response and tissue disorganisation with congested blood vessels. Our observations of the pulpo-dentin complex response to the self-etching adhesive resin systems correspond with similar observations made in humans $[1,12-14,17$, 19] and animals $[2,5,29]$. These found that even in the absence of bacterial contamination, pulp capping with different total etch and self-etch adhesive systems resulted in inflammatory reaction, predominantly with a chronic inflammatory cell infiltrate, presence of macrophages and giant cells around the resin globules within the pulp tissue, morphologic cell alterations, and hyalinisation of pulp cells $[2,5,29]$. Cui et al. [29] described more pronounced histological changes in pulpal tissue in teeth treated with self-etching adhesive systems (Clearfil SE Bond, ImpervaFluoroBond and Prompt L-Pop) than in a control pulp treated with $\mathrm{Ca}(\mathrm{OH})_{2}$, reporting that microleakage had a critical impact on pulp repair. It has been demonstrated that after APLP direct capping, the remaining pulp tissue exhibited varying degrees of inflammatory reactions, ranging from moderate to severe. Progressive extension of tissue necrosis over time also occurred $[2,5]$.

Better results, with less pronounced inflammation, were reported in a human study with the Prompt L-Pop system [7] and in animal studies [10-11, 20$-21]$. The extent of inflammation or necrosis of a small layer of pulp following capping with the Prompt L-Pop system was generally comparable to that caused by calcium hydroxide, and resulted from bacterial invasion caused by microleakage [7]. Contrary to our results, Kitasako et al. [20] revealed that self-etching adhesive resin system Clearfil Liner Bond 2 showed a significantly less extensive inflammatory cell infiltration than the hard-setting $\mathrm{Ca}(\mathrm{OH})_{2}$ following dentin bridging. These and other authors [7, 10-11, 20] have suggested that the chemical composition of resin monomers did not correlate with the histopathological responses.

Formation of the dentinal bridge at the interface between the pulp and pulp-capping material is a controversial issue because it may either be a sign of healing or a reaction to irritation $[8,11,38]$. In this study, we interpreted the formation of the dentinal bridge as a sign of healing. Incomplete amorphous dentin bridge formation with varying degrees of mineralisation occurred in three and two specimens of ASE and APLP, respectively. The odontoblast layer adjacent to the exposed pulp was disrupted or occasionally absent. Similarly to other published studies $[2,5,29]$, we found in none of the systems complete dentin 
bridge formation. Koliniotou-Koumpia et al. [2] and Silva et al. [5] reported a total absence of continuous hard tissue bridge formation after APLP capping, while Dycal induced a smaller inflammatory response and a more consistent formation of reparative dentine, similarly to our findings. The presence of chronic inflammatory response appears to play a role in the lack of complete dentin bridge formation [2].

Our findings contrast with the results of other studies which revealed that the bonding agent sealing on the cavities functioned as an effective barrier in the dentin bridges after bacterial challenges $[7,10$ $-11,20-21]$. Previously, it was reported that the response of pulpal tissue and formation of dentin bridges to various total-etch and self-etching systems was generally comparable to that of calcium hydroxide. For example, in a human study, Scarano et al. [7] found no differences in histological reaction between the self-etching system Prompt L-Pop, total-etch system Solid, and calcium hydroxide material after 15 days. In the specimens from all groups, there were active odontoblasts near the composite resins and the healing process with hard-tissue formation was more evident at the periphery of the exposed pulp [7].

After application of both studied self-etching resin systems and calcium hydroxide, we did not observe the presence of bacteria visualised by histological staining, which is in accordance with previous studies $[2,5,36]$. For example, Silva et al. [5] reported that bacteria were not identified by Brown and Brenn staining, but pulp necrosis occurred in $100 \%$ of the specimens capped with the APLP system. However, some authors [7, 9-11, 20-21, 28-29] have reported that the inflammation or necrosis of pulp was a consequence of bacterial invasion caused by microleakage rather than by irritation caused by the resin material itself. Medina et al. [21] compared the effect of three single-bottle and four self-etching primers on calcium hydroxide in exposed animal pulps and found that some of the self-etching adhesives induced a persistent moderate to severe inflammatory pulp response with positive bacterial staining. Cui et al. [29] observed positive bacterial staining and diverse pulpal responses in most specimens in experimental groups (Clearfil SE Bond, ImpervaFluoroBond and Prompt L-Pop). It has been reported that microleakage had critically affected pulpal repair and was not detrimental to cap the pulp with self-etching adhesive systems [7, 29]. Cox et al. [9] and Kitasako et al. [20] showed that dentinal bridges beneath a hard setting $\mathrm{Ca}(\mathrm{OH})_{2}$ contained multiple tunnel defects, which might serve as a pathway for bacterial contamination leading to infection or necrosis because of microleakage.
From the available data, it may be inferred that pulp inflammation and necrosis was primarily induced by the toxicity of the adhesive system composition. Indeed, the absence of dentin bridge formation may result in degenerative pulp alterations by all components of dentin-bonding systems and resin composites [1-2, 5, 22]. ASE and APLP consist of monomers such as dimethacrylate, phosphonic acid acrylate, HEMA, and Bis-GMA (Table 1), any of which may be toxic to pulp cells. Pashley et al. [40], reported that Prompt L-Pop was not completely polymerised on the dentine, and this observation suggests that a fresh application of primer and adhesive may exert an acute toxic effect on the pulp cells. The concentrations of AdheSE and Prompt L-Pop that caused $50 \%$ cell death were $0.30 \mathrm{mg} / \mathrm{mL}$ and 0.68 $\mathrm{mg} / \mathrm{mL}$, respectively [31]. In contrast, no cytotoxic effects of the dental adhesives were observed in a dentin barrier test device $[33,37]$. The concentrations of uncured resin components can evoke either immunosuppression or immunostimulation on mitogen-driven proliferation of determined cells [31, 41].

In summary, in the current study, the effect of ASE and APLP on the pulp was found to be comparable. In most cases, a significantly more pronounced inflammatory cell response and a considerably lower incidence of reparative dentin formation compared to the $\mathrm{CH}$ procedure was observed. None of the teeth in the experimental groups displayed a complete formation of a hard barrier. Thus, the present form of DBSs might not be the best choice of material in direct pulp capping treatment. While observations in this study extended throughout a period of 40 days, it is possible that over a longer period a complete formation of dentin bridge would have taken place after the use of ASE and APLP. Moreover, it has to be emphasised that we used animals with healthy young teeth with no inflammation, while in most clinical cases, pulp exposure frequently occurs by a carious process, in which bacteria and inflammation are present. For this reason, the results observed in animals' teeth may not be directly applicable to clinical conditions and human teeth, and prompt us to perform further clinical investigations and histopathologic studies on human subjects.

\section{References}

1. Costa CAS, Nascimento ABL, Teixeira HM, Fontana UF. Response of human pulps capped with a self-etching adhesive system. Dent Mater. 2001;17:230-240.

2. Koliniotou-Koumpia E, Tziafas D. Pulpal responses following direct pulp capping of healthy dog teeth with dentine adhesive systems. J Dent. 2005;33:639-647.

3. Silva AF, Tarquinio SB, Demarco FF, Piva E, Rivero ER. The influence of haemostatic agents on healing of healthy human dental pulp tissue capped with calcium hydroxide. Int Endod J. 2006;39:309-316. 
4. Silva GA, Lanza LD, Lopes-Júnior N, Moreira A, Alves JB. Direct pulp capping with a dentin bonding system in human teeth: a clinical and histological evaluation. Oper Dent. 2006;31:297-307.

5. Silva LA, Freitas AC, Carvalho FK, Queiroz AM, Nelson-Filho P, Porto-Neto ST. Direct pulp capping with a self-etching adhesive system: histopathologic evaluation in dogs' teeth. Oral Surg Oral Med Oral Pathol Oral Radiol Endod. 2009;108:34-40.

6. Subay RK, Asci S. Human pulpal response to hydroxyapatite and a calcium hydroxide material as direct capping agents. Oral Surg Oral Med and Oral Pathol.1993;76:485-492.

7. Scorano A, Manzon L, Di Giorgio R, Orsini G, Tripodi D, Piattelli A. Direct capping with four different materials in humans: histological analysis of odontoblast activity. $J$ Endod. 2003;29:729-734.

8. Nanci A. Ten Cate's Oral Histology: Development, Structure, and Function.7e. St. Louis: Elsevier Mosby; 2008.

9. Cox CF, Hafez AA, Akimoto N, Otsuki M, Suzuki S, Tarim B. Biocom-patibility of primer, adhesive and resin composite systems on non-exposed and exposed pulps of non-human primate teeth. Am J Dent.1998;11:55-63.

10. Kiba H, Hayakawa T, Nakanuma K, Yamazaki M, Yamamoto $\mathrm{H}$. Pulpal reactions to two experimental bonding systems for pulp capping procedures. J Oral Sci. 2000;42:69-74.

11. Kitasako Y, Murray PE, Tagami J, Smith AJ. Histomorphometric analysis of dentinal bridge formation and pulpal inflammation. Quintessence Int. 2002;33:600-608.

12. Accorinte ML, Loguercio AD, Reis A, Costa CA. Response of human pulps capped with different self-etch adhesive systems. Clin Oral Invest. 2008;12:119-127.

13. Fernandes AM, Silva GA, Lopes N Jr, Napimoga MH, Benatti BB, Alves JB. Direct capping of human pulps with a dentin bonding system and calcium hydroxide: an immunohistochemical analysis. Oral Surg Oral Med Oral Pathol Oral Radiol Endod. 2008;105:385-390.

14. Horsted-Bindslev P, Vilkinis V, Sidlauskas A. Direct capping of human pulps with a dentin bonding system or with calcium hydroxide cement. Oral Surg Oral Med Oral Pathol Oral Radiol Endod. 2003;96:591-600.

15. Accortine ML, Loguercio AD, Reis A, Muench A, Araujo. VC. Response of human pulp capped with a bonding agent after bleeding control with hemostatic agents. Oper Dent. 2005;30:147-155.

16. Hebling J, B Giro EM, Costa CA. Biocompatibility of an adhesive system applied to exposed human dental pulp. J Endod. 1999; 25:676-682.

17. Demarco FF, Tarquinio SB, Jaeger MM, Araujo VC, Matson E. Pulp response and cytotoxicity evaluation of 2 dentin bonding agents. Quintessence Int. 2001;32:211-220.

18. Matsuo T, Nakanishi T, Shimizu H, Ebisu S. A clinical study of direct pulp capping applied to carious-exposed pulps. J Endod. 1996;22:551-556.

19. Gwinnett AJ, Tay F. Early and intermediate time response of the dental pulp to an acid etch technique in vivo. Am J Dent. 1998;11:35-44.

20. Kitasako Y, Ikeda M, Tagami J. Pulpal responses to bacterial contamination following dentin bridging beneath hard setting calcium hydroxide and self-etching adhesive resin system. Dent Traumatol. 2008;24:201-206.

21. Medina VO 3rd, Shinkai K, Shirono M, Tanaka N, Katoh Y. Histopathologic study on pulp response to single-bottle and self-etching adhesive systems. Oper Dent. 2002;27:330-342.

22. Dominguez MS, Witherspoon DE, Gutmann JL, Opperman LA. Histological and scanning electron microscopy assessment of various vital pulp-therapy materials. J Endod. 2003;29: 324-333.
23. Lu Y, Liu T, Li X, Li H, Pi G. Histologic evaluation of direct pulp capping with a self-etching adhesive and calcium hydroxide in beagles. Oral Surg Oral Med Oral Pathol Oral Radiol Endod. 2006;102:78-84.

24. Hafez AA, Cox CF, Tarim B, Otsuki M, Akimoto N. An in vivo evaluation of hemorrhage control using sodium hypochlorite and direct capping with a one- or two-component adhesive system in exposed nonhuman primate pulps. Quintessence Int. 2002;33:261-272.

25. Edwall L. Methods of measuring dentinal, pulpal and periapical reactions to dental materials. Int Dent J. 1974;24: 251-257.

26. Costa CA, Oliveira MF, Giro EM, Hebling J. Biocompatibility of resin-based materials used as pulp-capping agents. Int Endod J. 2003;36:831-839.

27. Akimoto N, Momoi Y, Kohno A, Suzuki S, Otsuki M, Suzuki S, Cox CF. Biocompatibility of Clearfil Liner Bond 2 and Clearfil AP-X system on nonexposedand exposed primate teeth. Quintessence Int. 1998;29:177-188.

28. Cox CF, Keall CL, Keall HJ, Ostro E, Bergenholtz G. Biocompatibility of surface-sealed materials against exposed pulps. J Prosthet Dent. 1987;57:1-8.

29. Cui C, Zhou X, Chen X, Fan M, Bian Z, Chen Z. The adverse effect of self-etching adhesive systems on dental pulp after direct pulp capping. Quintessence Int. 2009;40: 26-34.

30. Sano H, Takatsu T, Ciucchi B, Horner JA, Matthews WG, Pashley DH. Nanoleakage: leakage within the hybrid layer. Oper Dent. 1995;20:18-25.

31. Demirci M, Hiller KA, Bosl C, Galler K, Schmalz G, Schweikl H. The induction of oxidative stress, cytotoxicity, and genotoxicity by dental adhesives. Dent Mater. 2008;24: 362-371.

32. Ratanasathien S, Wataha JC, Hanks CT, Dennison JB. Cytotoxic interactive effects of dentin bonding components on mouse fibroblasts. J Dent Res. 1995;74:1602-1606.

33. Rathke A, Alt A, Gambin N, Haller B. Dentin diffusion of HEMA released from etch-and-rinse and self-etch bonding systems. Eur J Oral Sci. 2007;115:510-516.

34. Koulaouzidou EA, Papazisis KT, Yiannaki E, Palaghias G, Helvatjoglu-Antoniades M. Effects of dentin bonding agents on the cell cycle of fibroblasts. J Endod. 2009:35:275-279.

35. Thomsen KB, Peutzfeldt A. Resin composites: strength of the bond to dentin versus mechanical properties. Clin Oral Invest.2007;11:45-49.

36. Hebling J, Giro EM, Costa CA. Human pulp response after an adhesive system application in deep cavities. J Dent. 1999;27:557-564.

37. Nowicka A, Buczkowska-Radlińska J, Lipski M, Lichota D, Woźniak K, Góra M, Kaczmarek W, Sikorska-Bochińska J. Response of dental pulp to self-etching adhesive systems used in indirect capping. A literature review. Ann Acad Med Stetin. 2009;55:79-83.

38. Modena KC, Casas-Apayco LC, Atta MT, Costa CA, Hebling J, Sipert CR, Navarro MF, Santos CF. Cytotoxicity and biocompatibility of direct and indirect pulp capping materials. J Appl Oral Sci. 2009;17:544-554.

39. Onur MA, Cehreli ZC, Tasman F, Gumrukcuoglu A. Effects of self-etching primers on vascular responses in rat carotid artery. J Oral Rehabil. 2004:31:574-578.

40. Pashley EL, Agee KA, Pashley DH, Tay FR. Effects of one versus two applications of an unfilled, all-in-one adhesive on dentine bonding. J Dent. 2002;30:83-90.

41. Schweikl H, Hiller KA, Bolay C, Kreissl M, Kreismann W, Nusser A, Steinhauser S, Wieczorek J, Vasold R, Schmalz G. Cytotoxic and mutagenic effects of dental composite materials. Biomaterials. 2005;26:1713-1719.

Submitted: 2 July, 2011

Accepted after reviews: 26 November, 2012 